\section{Praktisk og oppdatert lærebok}

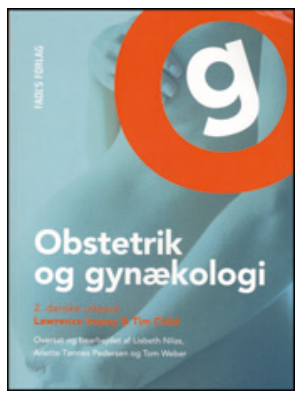

Lawrence Impey, Tim Child

2. utg. 363 s, tab, ill. København: FADL's

Forlag, 2012. Pris DKK 500

ISBN 978-87-7749-630-1

Læreboken er en dansk oversettelse og bearbeiding av en engelsk lærebok i fødselshjelp og kvinnesykdommer. Målgruppen er primært medisinstudenter. Boken egner seg også som oppslagsverk for andre som har med gravide og gynekologiske pasienter å gjøre. Jeg synes den praktiske kapittelinndelingen, med mange gode oversiktsbokser og nyttige flytskjemaer, i tillegg til en god kobling mellom basalkunnskap og klinisk praktisk arbeid, gjør at læreboken er velegnet for disse målgruppene.

Det ser ikke ut som om denne danske læreboken avviker i oppsettet fra den engelske originalboken, som stykkevis er gratis tilgjengelig via Internett. Jeg er dermed usikker på hvor stor tilleggsnytte norske medisinstudenter skulle ha av å lese en bok på dansk i stedet for originalboken på engelsk, som er en del billigere. Den danske boken har imidlertid kapitler som er tilpasset dansk lovgivning, klinisk praksis og svangerskapsomsorg, og de som har bearbeidet den til dansk, viser også til nyttige danske nettsteder for nasjonale retningslinjer (www.dsog/guidelines). Danske og engelske retningslinjer og praksis vil i noen unntakstilfeller skille seg fra norske forhold, slik som kombinasjonen av ultralyd- og blodprøvescreening (for bl.a. alvorlige misdannelser og trisomi) i første og andre trimester av svangerskapet i Danmark og England. En dansk eller engelsk utgave av læreboken vil derfor for medisinstudenter i Norge med fordel kunne suppleres med informasjon fra norske forhold, inkludert norsk lovgivning, fødselsepidemiologi og organisering av svangerskapsomsorg, slik som er dekket i den norske læreboken i fagområdet fra 2010.

Denne danske/engelske læreboken er blant de beste og mest praktiske lærebøkene for medisinstudenter som jeg har vurdert. Ved siden av enkle og gode forklaringer innen hvert kapittel, rikelig supplert med oversiktstabeller, avsluttes boken med oppsummeringer av klinisk håndtering av vanlige gynekologiske og obstetrisk kliniske problemstillinger, med henvisning til lærebokens kapitler. Den kliniske pasientrettede vinklingen, fra diagnostisering til håndtering, gjør boken velegnet også som forberedelse for en praktisk rettet eksamensform som er innført ved 9. semester ved Universitetet i Oslo (Objective Structured Clinical Examination, OSCE).

Den engelske fjerdeutgaven av boken ble gitt ut i 2012, mens denne danske 2012-oversettelsen er bygd på tredje utgave fra 2008. Den danske oversettelsen virker likevel oppdatert, med bl.a. informasjon om vaksinering med HPV-profylakse i Danmark, mens den mer kontroversielle rollen for HPV-testing i cervixscreeningen er utelatt.

Jeg nøler ikke med å anbefale boken som lære- og oppslagsbok til studenter, leger og helsepersonell som har sitt virke innenfor fagområdet fødselshjelp og kvinnesykdommer.

\section{Fremragende om antibiotika}

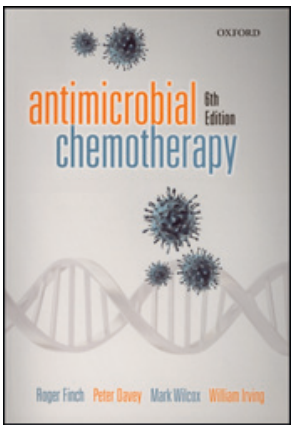

Roger Finch, Peter Davey,

Mark H. Wilcox et al.

\section{Antimicrobial chemotherapy}

6. utg. 399 s, tab, ill. Oxford: Oxford University

Press, 2012. Pris GBP 40

ISBN 978-0-19-969765-6

Målgruppen er både medisinstudenter og leger. Intensjonen er å fremheve prinsipper for rasjonell behandling av infeksjonssykdommer og å gi praktisk veiledning i hvordan man behandler de vanligste infeksjonssykdommene med færrest mulig økologiske og toksiske bivirkninger.

Denne sjette utgaven er bygd opp med fire hoveddeler med i alt 36 underkapitler. Forfatterne starter med å gjennomgå virkningsmekanismer for antibiotika, antivirale midler og parasittmidler. Deretter følger ca. 30 sider om resistens mot antimikrobielle midler og utvikling og spredning av Clostridium difficile. Hoveddelen utgjør ca. 70 sider og handler om generelle prinsipper for bruk av antimikrobielle midler. Her legger forfatterne vekt på hvor viktig det er med korrekt prøvetaking og farmakokinetiske og farmakodynamiske prinsipper for antimikrobiell terapi. I siste hoveddel gjennomgår de først behandlingen av de vanligste bakterieinfeksjonene og deretter hiv og hepatitt.

Teksten er lettlest med et klart språk. Illustrasjonene og tabellene er instruktive og bidrar til å gjøre lesingen lettere. Boken er i stor paperbackutgave. Det eneste negative er dårlig papirkvalitet med stor grad av gjennomskinnelighet.

Hvis jeg skal fremheve noe, må det være kapitlene om hvorfor og hvordan mikrobene utvikler resistens og hvordan feil bruk og overforbruk av antibiotika kan selektere frem resistens og endringer av den normale bakteriefloraen. Forskjellen på naturlig og ervervet resistens blir omtalt, og problemene med kryssresistens og fremvekst av sjeldne bakterier og C. difficile blir lett å forstå. Kapitlene om generelle prinsipper for behandling av infeksjoner basert på farmakokinetiske og farmakodynamiske prinsipper er gode. Likeledes er kapitlene om utvikling og bruk av retningslinjer og styring av antibiotika fremragende. Disse kapitlene gir en god forståelse av hvor viktig det er å ta hensyn til de økologiske bivirkningene av antibiotika, slik at man kan unngå eller utsette resistensutvikling og andre bivirkninger. Det siste kapitlet handler om utvikling og markedsføring av antibiotika, hvor problemet med manglende utvikling av nye antibiotika blir omtalt.

Dette er en meget god bok som ikke bare er en kokebok. Forfatterne problematiserer i tillegg antimikrobiell behandling, noe som er kjærkomment $i$ en tid hvor feilbruk og overforbruk av antibiotika er et økende problem også i Norge. Boken passer for norske forhold, og jeg anbefaler den på det varmeste.

Dag Berild

Infeksjonsavdelingen

Oslo universitetssykehus, Ullevål

\title{
Annetine Staff
}

Kvinne- og barneklinikken 